\title{
Leadership and Job Satisfaction: Implications for Leaders of Accountants
}

\author{
Yu Sun1, Esther Gergen1, Michelle Avila², Mark Green' \\ ${ }^{1}$ Department of Leadership Study, Our Lady of the Lake University, San Antonio, TX, USA \\ ${ }^{2}$ Accounting Department, Our Lady of the Lake University, San Antonio, TX, USA \\ Email: ysun@ollusa.edu, esgergen@lake.ollusa.edu, miavila@ollusa.edu, mtgreen@ollusa.edu
}

Received 5 December 2015; accepted 19 March 2016; published 22 March 2016

Copyright (C) 2016 by authors and Scientific Research Publishing Inc.

This work is licensed under the Creative Commons Attribution International License (CC BY).

http://creativecommons.org/licenses/by/4.0/

c) (i) Open Access

\begin{abstract}
This study conducted a review of the meta-analytic literature which correlated leadership and job satisfaction. Twenty-five meta-analytic correlations were extracted and analyzed in order to focus specifically on how leadership affected worker job satisfaction. Results indicated that charismatic and transformational leadership behaviors had the highest positive correlations with worker job satisfaction while non-contingent punishment and abusive supervision showed low negative relationships to worker job satisfaction. Implications to both overall job satisfaction and specific applications to satisfaction and attrition in the financial industry are discussed.
\end{abstract}

\section{Keywords}

Job Satisfaction, Transformational Leadership, Charismatic Leadership, Maslow's Hierarchy

\section{Introduction}

Although there is no dearth of opinion on web sites and blogs about what makes accountants satisfied in their jobs, there is limited information in the peer-reviewed literature. Glodstein [1] found that accountant's emotional intelligence was correlated with job satisfaction. Barac and Tadic [2] found that the complexity of the regulatory accounting framework and frequent changes have a statistically significant impact on job satisfaction of accounting practitioners. Kass-Shraibman [3] found that accountant locus of control and earnings were related to job satisfaction.

Despite the small amount of peer-reviewed literature specific to predictors of accountant job satisfaction, there is a broad body of literature on job satisfaction in general. There are over 85 meta-analytic studies in the peer-reviewed literature related to correlates of worker job satisfaction. Across this meta-analytic body of literature, there are over 150 different variables for which one or more meta-analytic correlations have been reported. 
Because some variables are meta-analyzed in more than one journal article, these 85 meta-analytic studies represent over 200 unique meta-analytic correlations and over 7500 effect sizes.

Among the meta-analytic correlations in the job satisfaction literature, 25 are related to leadership and worker job satisfaction. This article synthesizes what these 25 meta-analytic correlations indicate about leadership and job satisfaction. Because definitions of variables can vary from researcher to researcher, a list of how the variables were defined in each study is included in Appendix A.

The numerous accounting scandals reported in the beginning of the twenty-first century led to an emphasis in preparing accountants with strong ethical and leadership skills. This is being reflected in the rigorous continuing education requirements for CPAs and in the significant changes in the CPA exam. The AICPA's CPA Horizons 2025 Report [4] identified the core values and core competencies in the accounting profession. One of the most important core values that were identified was integrity. In addition, one of the six core competencies identified was leadership. The AICPA Horizon's report defined leadership as "CPAs are adept at influencing, inspiring, and motivating others to facilitate change and achieve excellence". Integrity was defined as "CPAs conduct themselves with integrity and honesty, holding themselves to rigorous standards of professional ethics". The American Institute of Certified Public Accountants concluded that effective leadership and ethical accountants are vital in preserving the public's trust in the accounting profession.

Given the likely importance of leadership to accountant job satisfaction, but the limited peer-reviewed literature related to accountant job satisfaction, generalizable results from the meta-analytic literature related to leadership and job satisfaction are an important resource. Table 1 provides the results of various variables from the meta-analytic literature.

Table 1. Meta-Analytic correlates of leadership and worker job satisfaction.

\begin{tabular}{|c|c|c|c|c|}
\hline Year & Variable and Article Code & $\mathrm{k}$ & $\mathrm{N}$ & Effect Size \\
\hline 2011 & Leader Gender (Deru2) [5] & 8 & 3824 & 0.04 \\
\hline 2006 & Contingent Punishment (Pods2) [6] & 19 & 15,897 & 0.12 \\
\hline 2006 & Non Contingent Reward (Pods2) [6] & 10 & 4089 & 0.17 \\
\hline 2004 & Initiation of Structure (Judg) [7] & 72 & 10,317 & 0.22 \\
\hline 2013 & Abusive Supervision (Schy) [8] & 10 & 2724 & -0.31 \\
\hline 2013 & Bad Leadership (Schy) & 21 & 8707 & -0.34 \\
\hline 2006 & Non Contingent Punishment (Pods2) [6] & 23 & 7130 & -0.39 \\
\hline 2012 & Leader Humor (Mesm) [9] & 5 & 1619 & 0.39 \\
\hline 2004 & Consideration (Judg)) [7] & 76 & 11,374 & 0.40 \\
\hline 2009 & Perceptions of Leader Climate (Park1) [10] & 24 & 5420 & 0.41 \\
\hline 2014 & Ethical Leadership (Ng1) [11] & 10 & 2983 & 0.42 \\
\hline 2014 & Leadership Support (Sabe) [12] & 21 & 6099 & 0.44 \\
\hline 2014 & Person-Supervisor Fit North America (Oh) [13] & 5 & 1199 & 0.44 \\
\hline 2012 & Leader-Member Exchange (Rock) [14] & 19 & 4608 & 0.45 \\
\hline 2002 & Trust in Organizational Leadership (Dirk) [15] & 13 & 3708 & 0.48 \\
\hline 2012 & Leader-Member Exchange (Dule) [16] & 88 & 22,520 & 0.49 \\
\hline 2006 & Perceived Leader Integrity (Davi) [17] & 9 & 2651 & 0.50 \\
\hline 2006 & Contingent Reward (Pods2) [6] & 43 & 11,461 & 0.52 \\
\hline 2008 & Perceived Supervisor Support (Ng4) [11] & 59 & 32,339 & 0.52 \\
\hline 2012 & Leader-Member Exchange (Rock) [14] & 78 & 17,473 & 0.55 \\
\hline 2002 & Trust in Direct Leader (Dirk) [15] & 19 & 6863 & 0.55 \\
\hline 2004 & Transformational Behaviors (Judg2) [18] & 18 & 5279 & 0.58 \\
\hline 2004 & Contingent Reward (Judg2) [18] & 6 & 1933 & 0.64 \\
\hline 2013 & Transformational Leadership (Barl) [19] & 14 & NA & 0.64 \\
\hline 2000 & Charismatic Leadership (Degr2) [5] & 14 & 3832 & 0.77 \\
\hline
\end{tabular}

Note: $\mathrm{k}$ is the number of effect sizes, $\mathrm{N}$ is the total sample size from those $\mathrm{k}$ studies. The specific effect size calculation is included in Appendix B. NA-the Barlow meta-analysis did not report the sample size N. 


\section{Interpreting the Meta-Analytic Literature for Leadership and Job Satisfaction}

One way to interpret the findings for leadership and job satisfaction is through the lens of Maslow's hierarchy [20]. Maslow postulated that individuals need to have their base or hygiene needs of biological and safety met before they tend to desire love, belongingness and esteem.

Although Maslow's Hierarchy is a seminal theory that is over 55 years old, it is still used in the peer-reviewed literature. Since 1961 there have been over 550 peer-reviewed articles published in which the terms Maslow and hierarchy were included in the article abstract. Over 150 of the over 500 peer-reviewed articles have been published since 2010. A search of the online retailer Amazon, found over 5000 books that include aspects of the theory. Consequently, Maslow's Hierarchy is likely familiar to many leaders and managers.

A simple way to envision Maslow's hierarchy is a group of passengers who become stranded on a deserted island. Among the first things they will likely worry about are food, water and shelter.

Those levels of Maslow's hierarchy will need to be fulfilled before the passengers begin to concern themselves with friendship a possible romantic relationships with other stranded passengers.

The love and belongingness level of Maslow's hierarchy would need to be fulfilled before the passengers began to worry about their esteem (Table 2).

It is not an absurd leap to think about Maslow's hierarchy in a workplace setting. Biological and physical needs are things such as air conditioning and heating at the place of work.

Safety needs can include the idea that the workplace is safe, but, beyond that, it can include the idea that the worker has some degree of job security. If the worker believes she or he has a future in the organization, then making good friends at work becomes something the worker desires.

Once the worker feels as if she or he is a good fit in the organization, she or he may likely want to feel empowered and valued by others. Ultimately, the worker may want to feel as if she or he is growing and becoming more self-actualized through the work she or he does (Table 3).

Table 4 provides a conceptual model that overlays the idea of a hierarchy of needs in the workplace onto the meta-analytic literature related to leadership and job satisfaction.

While not a perfect fit, there is a broad pattern among the meta-analytic correlations and the concept of Maslow's hierarchy in the workplace. Aspects of leadership such as contingent punishment, non-contingent reward and initiation of structure likely attend to workers' needs for feelings of safety/job security in the workplace. These aspects are likely related to worker feelings of keeping one’s job by "staying out of trouble” and following

Table 2. Maslow’s hierarchy (traditional).

$\begin{aligned} & \text { Biological and } \\ & \text { Physiological }\end{aligned}$
$\begin{aligned} & \text { Includes air, food, drink, shelter, warmth, sex, sleep } \\ & \text { Safety }\end{aligned}$
$\begin{aligned} & \text { Love and } \\ & \text { Belongingness }\end{aligned}$
$\begin{aligned} & \text { Esteem } \\ & \text { Includes friendship, intimacy, affection and love, from work group, family, friends, romantic relationships }\end{aligned}$
Self-Actualization

Table 3. Maslow’s hierarchy (workplace example).

\begin{tabular}{ll}
$\begin{array}{l}\text { Biological and } \\
\text { Physiological }\end{array}$ & Can include things such as water, air conditioning, heat and so forth in the work environment \\
Safety & Can include the sense that one's job is secure if she or he does a good job \\
$\begin{array}{l}\text { Love and } \\
\text { Belongingness }\end{array}$ & $\begin{array}{l}\text { Can include feelings that one is a good fit in the organization and that the culture enables her } \\
\text { or him to make friends. } \\
\text { Can include the ideas of feeling empowered and valued for the contributions one makes to the } \\
\text { organization } \\
\text { Can include realizing personal potential, self-fulfillment, seeking personal growth and peak } \\
\text { experiences in the workplace }\end{array}$ \\
\hline
\end{tabular}


Table 4. Meta-analytic correlates juxtaposed with Maslow’s hierarchy.

\begin{tabular}{|c|c|c|c|c|c|}
\hline Year & $\begin{array}{l}\text { Variable and Article } \\
\text { Code }\end{array}$ & $\mathrm{K}$ & $\mathrm{N}$ & Effect Size & $\begin{array}{c}\text { Broad Association } \\
\text { with Maslow’s } \\
\text { Hierarchy }\end{array}$ \\
\hline 2011 & $\begin{array}{l}\text { Leader Gender } \\
\text { (Deru2) }\end{array}$ & 8 & 3824 & 0.04 & \\
\hline 2006 & $\begin{array}{c}\text { Contingent } \\
\text { Punishment (Pods2) }\end{array}$ & 19 & 15,897 & 0.12 & Safety \\
\hline 2006 & $\begin{array}{l}\text { Non Contingent } \\
\text { Reward (Pods2) }\end{array}$ & 10 & 4089 & 0.17 & Job Security \\
\hline 2004 & $\begin{array}{c}\text { Initiation of Structure } \\
\text { (Judg) }\end{array}$ & 72 & 10,317 & 0.22 & \\
\hline 2013 & $\begin{array}{l}\text { Abusive Supervision } \\
\text { (Schy) }\end{array}$ & 10 & 2724 & -0.31 & \\
\hline 2013 & $\begin{array}{l}\text { Bad Leadership } \\
\text { (Schy) }\end{array}$ & 21 & 8707 & -0.34 & \\
\hline 2006 & $\begin{array}{c}\text { Non Contingent } \\
\text { Punishment (Pods2) }\end{array}$ & 23 & 7130 & -0.39 & \\
\hline 2012 & $\begin{array}{l}\text { Leader Humor } \\
\quad \text { (Mesm) }\end{array}$ & 5 & 1619 & 0.39 & Belonging \\
\hline 2004 & $\begin{array}{l}\text { Consideration } \\
\text { (Judge) }\end{array}$ & 76 & 11,374 & 0.40 & Cultural Fit \\
\hline 2009 & $\begin{array}{l}\text { Perceptions of } \\
\text { Leader Climate } \\
\text { (Park1) }\end{array}$ & 24 & 5420 & 0.41 & Workplace Friends \\
\hline 2014 & $\begin{array}{l}\text { Ethical Leadership } \\
\text { (Ng1) }\end{array}$ & 10 & 2983 & 0.42 & \\
\hline 2014 & $\begin{array}{l}\text { Leadership Support } \\
\text { (Sabe) }\end{array}$ & 21 & 6099 & 0.44 & \\
\hline 2014 & $\begin{array}{l}\text { Person-Supervisor } \\
\text { Fit North America } \\
\text { (Oh) }\end{array}$ & 5 & 1199 & 0.44 & \\
\hline 2012 & $\begin{array}{l}\text { Leader-Member } \\
\text { Exchange (Rock) }\end{array}$ & 19 & 4608 & 0.45 & \\
\hline 2002 & $\begin{array}{c}\text { Trust in } \\
\text { Organizational } \\
\text { Leadership (Dirk) }\end{array}$ & 13 & 3708 & 0.48 & \\
\hline 2012 & $\begin{array}{l}\text { Leader-Member } \\
\text { Exchange (Dule) }\end{array}$ & 88 & 22,520 & 0.49 & Esteem \\
\hline 2006 & $\begin{array}{l}\text { Perceived Leader } \\
\text { Integrity (Davi) }\end{array}$ & 9 & 2651 & 0.50 & Empowerment \\
\hline 2006 & $\begin{array}{l}\text { Contingent Reward } \\
\text { (Pods2) }\end{array}$ & 43 & 11,461 & 0.52 & \\
\hline 2008 & $\begin{array}{l}\text { Perceived Supervisor } \\
\text { Support (Ng4) }\end{array}$ & 59 & 32,339 & 0.52 & \\
\hline 2012 & $\begin{array}{l}\text { Leader-Member } \\
\text { Exchange (Rock) }\end{array}$ & 78 & 17,473 & 0.55 & \\
\hline 2002 & $\begin{array}{l}\text { Trust in Direct } \\
\text { Leader (Dirk) }\end{array}$ & 19 & 6863 & 0.55 & Self-Actualization \\
\hline 2004 & $\begin{array}{l}\text { Transformational } \\
\text { Behaviors (Judg2) }\end{array}$ & 18 & 5,279 & 0.58 & Fulfillment \\
\hline 2004 & $\begin{array}{l}\text { Contingent Reward } \\
\text { (Judg2) }\end{array}$ & 6 & 1933 & 0.64 & Personal Growth \\
\hline 2013 & $\begin{array}{l}\text { Transformational } \\
\text { Leadership (Barl) }\end{array}$ & 14 & NA & 0.64 & \\
\hline 2000 & $\begin{array}{c}\text { Charismatic } \\
\text { Leadership (Degr2) }\end{array}$ & 14 & 3832 & 0.77 & \\
\hline
\end{tabular}


the structure that exists in the job.

Stronger correlations, are found for areas of leadership that are broadly associated with workers' needs to feel that they are a good fit for the organization and that other workers befriend them. Aspects of leadership such as leader consideration and feelings that the leader establishes a good workplace climate are provide workers a sense that the "belong" in the organization.

Even stronger correlations are found for aspect of trust in one's leader, and feelings of leader support. These aspects of leadership allow workers to feel that they can engage in aspects of empowered work in an environment safe from punitive outcomes and shared accountability between leader and follower.

The strongest meta-analytic correlations were found for leader transformational behaviors and leader charisma. The concept of transformational leadership connotes that the leader is helping the worker transform, not only into a better workers, but also a better person overall. This aspect of leader behavior aligns well with the idea of worker self-actualization and personal development.

\section{Implications for Leaders}

Finding and retaining qualified accountants continue to be a challenge in the public accounting sector. Accountants stay a few years in public accounting and then move on to different jobs. As a result, there is a high job turnover rate in this industry. According to the 2014 Big Four Firm Performance Analysis, the combined 2014 turnover rate for all Big Four public accounting firms was 27\%. These firms are Deloitte LLP, Ernst \& Young, KPMG LLP, and PricewaterhouseCoopers. High turnover is costly for employers so it is beneficial to analyze the causes of turnover in this industry [4].

According to Chong and Monroe [21], one of the factors leading to job turnover is job satisfaction. Some variables that affect job satisfaction are job burnout, long hours, stress, routine tasks, work/life balance, and role ambiguity. The "busy season" in public accounting entails long hours (60 - 80 hours per week) and numerous deadlines that contribute to low job satisfaction. These and other financial sector leadership challenges provide specific opportunities for the development and implementation of value based leadership practices like Transformational and Charismatic leadership that has the potential to increase job satisfaction. This study, then, provides insight into the practical applications of various leadership behaviors and their effect on job satisfaction that might serve to address the aforementioned challenges in retaining qualified accounting and financial field's professionals in the public sector. Although this study suggests that charismatic and transformational leadership style is the most effective leadership styles, CPA firms tend to use a transactional leadership style due to the routine nature of the audit and tax services. However, CPA firms would greatly benefit from adopting the transformational leadership style to reduce employee turnover and motivate employees.

Additionally, this study provides implications for future research that includes the analysis of factors unique to job satisfaction and turnover in the accounting and financial private sector, some of which this research does not specifically address.

\section{References}

[1] Glodstein, D. (2014) Examining the Relationship between Emotional Intelligence of Accountants and Job Satisfaction. Dissertation Abstracts International Section A, 75, 5.

[2] Barać, Ž.A. and Tadić, I. (2011) Impact of Accounting Regulatory Framework Complexity on Accountant’s Job Satisfaction in Croatia. Management: Journal of Contemporary Management Issues, 16, 1-21.

[3] Kass-Shraibman, F. (2008) An Examination of the Job Satisfaction of Certified Public Accountants as It Relates to Their Area of Practice and Their Locus of Control. Dissertation Abstracts International Section A, 69, 855.

[4] CPA Horizons 2025 Report. http://www.aicpa.org/research/cpahorizons2025/pages/cpahorizonsreport.aspx

[5] Derue, D.S., Nahrgang, J.D., Wellman, N. and Humphrey, S.E. (2011) Trait and Behavioral Theories of Leadership: An Integration and Meta-Analytic Test of Their Relative Validity. Personnel Psychology, 64, 7-52. http://dx.doi.org/10.1111/j.1744-6570.2010.01201.x

[6] Podsakoff, P.M., Bommer, W.H., Podsakoff, N.P. and MacKenzie, S.B. (2006) Relationships between Leader Reward and Punishment Behavior and Subordinate Attitudes, Perceptions, and Behaviors: A Meta-Analytic Review of Existing and New Research. Organizational Behavior and Human Decision Processes, 99, 113-142. http://dx.doi.org/10.1016/j.obhdp.2005.09.002

[7] Judge, T.A., Piccolo, R.F. and Ilies, R. (2004) The Forgotten Ones? The Validity of Consideration and Initiating 
Structure in Leadership Research. Journal of Applied Psychology, 89, 36-51. http://dx.doi.org/10.1037/0021-9010.89.1.36

[8] Schyns, B. and Schilling, J. (2013) How Bad Are the Effects of Bad Leaders? A Meta-Analysis of Destructive Leadership and Its Outcomes. The Leadership Quarterly, 24, 138-158. http://dx.doi.org/10.1016/j.leaqua.2012.09.001

[9] Mesmer-Magnus, J., Glew, D.J. and Viswesvaran, C. (2012) A Meta-Analysis of Positive Humor in the Workplace. Journal of Managerial Psychology, 27, 155-190. http://dx.doi.org/10.1108/02683941211199554

[10] Parker, C.P., Baltes, B.B., Young, S.A., Huff, J.W., Altmann, R.A., Lacost, H.A. and Roberts, J.E. (2003) Relationships between Psychological Climate Perceptions and Work Outcomes: A Meta-Analytic Review. Journal of Organizational Behavior, 24, 389-416. http://dx.doi.org/10.1002/job.198

[11] Ng, T.W. and Feldman, D.C. (2015) Ethical Leadership: Meta-Analytic Evidence of Criterion-Related and Incremental Validity. Journal of Applied Psychology, 100, 948-965.

[12] Saber, D.A. (2014) Frontline Registered Nurse Job Satisfaction and Predictors over Three Decades: A Meta-Analysis from 1980 to 2009. Nursing Outlook, 62, 6. http://dx.doi.org/10.1016/j.outlook.2014.05.004

[13] Oh, I.-S., Guay, R.P., Kim, K., Harold, C.M., Lee, J.-H., Heo, C.-G. and Shin, K.-H. (2014) Fit Happens Globally: A Meta-Analytic Comparison of the Relationships of Person-Environment Fit Dimensions with Work Attitudes and Performance across East Asia, Europe, and North America. Personnel Psychology, 67, 99-152. http://dx.doi.org/10.1111/peps.12026

[14] Rockstuhl, T., Dulebohn, J.H., Ang, S. and Shore, L.M. (2012) Leader-Member Exchange (LMX) and Culture: A Meta-Analysis of Correlates of LMX across 23 Countries. Journal of Applied Psychology, 97, 1097-1130. http://dx.doi.org/10.1037/a0029978

[15] Dirks, K.T. and Ferrin, D.L. (2002) Trust in Leadership: Meta-Analytic Findings and Implications for Research and Practice. Journal of Applied Psychology, 87, 611-628. http://dx.doi.org/10.1037/0021-9010.87.4.611

[16] Dulebohn, J.H., Bommer, W.H., Liden, R.C., Brouer, R.L. and Ferris, G.R. (2012) A Meta-Analysis of Antecedents and Consequences of Leader-Member Exchange: Integrating the Past with an Eye toward the Future. Journal of Management, 38, 1715-1759. http://dx.doi.org/10.1177/0149206311415280

[17] Davis, A.L. and Rothstein, H.R. (2006) The Effects of the Perceived Behavioral Integrity of Managers on Employee Attitudes: A Meta-analysis. Journal of Business Ethics, 67, 407-419. http://dx.doi.org/10.1007/s10551-006-9034-4

[18] Judge, T.A. and Piccolo, R.F. (2004) Transformational and Transactional Leadership: A Meta-Analytic Test of Their Relative Validity. Journal of Applied Psychology, 89, 755-768. http://dx.doi.org/10.1037/0021-9010.89.5.755

[19] Barlow, K.M. (2013) A Meta-Analysis of Transformational Leadership and Subordinate Nursing Personnel Organizational Commitment, Job Satisfaction, and Turnover Intentions. Dissertation Abstracts.

[20] Maslow, A.H. (1968) Toward a Psychology of Being. Van Nostrand, New York.

[21] Chong, V.K. and Monroe, G.S. (2013) The Impact of the Antecedents and Consequences of Job Burnout on Junior Accountants’ Turnover Intentions: A Structural Equation Modelling Approach. Accounting \& Finance, 55, 105-132. http://dx.doi.org/10.1111/acfi.12049 


\section{Appendix A}

The definitions of variables used are as followings:

Abusive Supervision is the extent to which supervisors engage in the sustained display of hostile verbal and nonverbal behaviors, excluding physical contact.

Bad Leadership: Search terms used in the concept of bad leadership were abusive supervision, supervisor abuse, abusive leadership, bossing, despotic leadership, despotic supervision, destructive leadership, destructive supervision, narcissistic leadership, narcissistic supervision, negative leadership, negative supervision, petty tyranny, psychopathic leadership, psychopathic supervision, toxic leadership, toxic supervision, tyrannical leadership and tyrannical supervision.

Charismatic Leadership: The authors anchored their meta-analyses on two seminal views of charismatic leadership. Charismatic leaders excite and transform previously dispirited followers into active followers by heightening motivation and instilling a sense of purpose (Burns, 1978).

Consideration is defined as regarding the comfort, well-being, status and contributions of followers.

Contingent Punishment (Pods2) describes workers' beliefs that punishment they receive from an organization is linked to their behaviors in the organization.

Contingent Reward (Judg2) describes leaders who engage in a constructive path-goal transaction of reward for performance. Leaders clarify expectations, exchange promises and resources, arrange mutually satisfactory agreements, negotiate for resources, exchange assistance for effort and provide recommendations for successful follower performance.

Ethical Leadership was based on searches using the phrases ethical leadership and moral leadership.

Initiation of Structure (Judg) is defined as the leader clearly defining her or his own role and letting followers know what is expected.

Leader Humor: The researcher categorized humor into four types: coping/self-enhancing humor, affinitive humor, self-defeating humor and aggressive humor. In their meta-analysis positive, humor included either coping/self enhancing humor or affinitive humor.

Leader-Member Exchange refers to the quality of the relationship between the leader and follower.

Leadership Support was defined as leadership that is perceived positively or negatively by employees, which can assist or affect them in their work, nursing administration, and the visibility and power and communication from the chief nursing officer.

Non-Contingent Punishment describes workers' beliefs that punishment they receive from an organization is linked to something other than the contributions they make to the organization such as equality, need, seniority and so forth.

Non-Contingent Reward (Pods2) describes workers' beliefs that the outcomes they receive from an organization are linked to something other than the contributions they make to the organization such as equality, need, seniority and so forth.

Perceived Leader Integrity concerns the fit between what the manager says and what the manager does, and includes the perception of managerial behavior that is supportive of the organization's mission and value statements as well as employees' perception that the manager acts in accordance with how someone who holds the position of manager "ought" to act.

Perceived Supervisor Support was defined as the beliefs employees hold regarding the extent to which supervisors provide instrumental (work-related) and emotional assistance.

Perceptions of Leader Climate perceptions enable an individual to interpret events, predict possible outcomes, and gauge the appropriateness of their subsequent actions. Leader perceptions are the ability of an employee to do this related to their leader.

Person-Supervisor Fit is the degree of compatibility or match between individuals and $t$ heir leaders.

Transformational Leadership/Behaviors involves a leader-follower exchange relationship in which the followers feel trust, loyalty and respect toward the leader and are motivated to do more than originally expected.

Transformational Leadership involves a leader-follower exchange relationship in which the followers feel trust, loyalty and respect toward the leader and are motivated to do more than originally expected.

Trust in Direct Leader is a psychological state that reflects employees' willingness to become vulnerable to the leader (that is, to assume some risk or forego some promised reward in the short run) because employees have positive expectations of their leaders' intentions and behaviors in the long run. 


\section{Appendix B}

Statistics reported in Table 1 and Table 4.

\begin{tabular}{|c|c|c|}
\hline $\begin{array}{l}\text { Code } \\
\text { Used }\end{array}$ & Statistic Reported & Reference \\
\hline Barl & $\begin{array}{l}\text { Mean Weighted } \\
\text { Effect Size }\end{array}$ & $\begin{array}{l}\text { Barlow, K.M. (2013) A Meta-Analysis of Transformational Leadership and Subordinate } \\
\text { Nursing Personnel Organizational Commitment, Job Satisfaction, and Turnover Intentions. }\end{array}$ \\
\hline Davi & $\begin{array}{l}\text { Mean Correlation Corrected } \\
\text { for Error of Measurement in } \\
\text { Both Predictor and Criterion } \\
\text { Variable }\end{array}$ & $\begin{array}{l}\text { Davis, A.L. and Rothstein, H.R. (2006) The Effects of the Perceived Behavioral Integrity of } \\
\text { Managers on Employee Attitudes: A Meta-analysis. Journal Of Business Ethics, 67, 407-419. }\end{array}$ \\
\hline Degr & $\begin{array}{l}\text { Sample Size Weighted Mean } \\
\text { Correlation }\end{array}$ & $\begin{array}{l}\text { DeGroot, T. and Kiker, D.S. (2003) A Meta-Analysis of the Non-Monetary Effects of } \\
\text { Employee Health Management Programs. Human Resource Management, 42, 53-69. }\end{array}$ \\
\hline Degr2 & $\begin{array}{l}\text { Estimated } \\
\text { True Correlation }\end{array}$ & $\begin{array}{l}\text { DeGroot, T, Kiker, D.S. and Cross, T.C. (2000) A Meta-Analysis to Review } \\
\text { Organizational Outcomes Related to Charismatic Leadership. Canadian Journal of } \\
\text { Administrative Sciences (Canadian Journal of Administrative Sciences), 17, 356-371. }\end{array}$ \\
\hline Deru2 & $\begin{array}{l}\text { Mean Correlation } \\
\text { Corrected for } \\
\text { Measurement Error in Both } \\
\text { the Predictor and Criterion } \\
\text { Scores }\end{array}$ & $\begin{array}{l}\text { Derue, D.S., Nahrgang, J.D., Wellman, N. and Humphrey, S.E. (2011) Trait and } \\
\text { Behavioral Theories of Leadership: An Integration and Meta-Analytic Test of Their Relative } \\
\text { Validity. Personnel Psychology, 64, 7-52. } \\
\text { http://dx.doi.org/10.1111/j.1744-6570.2010.01201.x }\end{array}$ \\
\hline Dirk & $\begin{array}{l}\text { Mean Weighted } \\
\text { Correlation }\end{array}$ & $\begin{array}{l}\text { Dirks, K.T. and Ferrin, D.L. (2002) Trust in Leadership: Meta-Analytic Findings and } \\
\text { Implications for Research and Practice. Journal of Applied Psychology, 87, 611-628. } \\
\text { http://dx.doi.org/10.1037/0021-9010.87.4.611 }\end{array}$ \\
\hline Dule & Mean Weighted Correlation & $\begin{array}{l}\text { Dulebohn, J.H., Bommer, W.H., Liden, R.C., Brouer, R.L. and Ferris, G.R. (2012) A } \\
\text { Meta-Analysis of Antecedents and Consequences of Leader-Member Exchange: Integrating } \\
\text { the Past with an Eye toward the Future. Journal of Management, 38, 1715-1759. } \\
\text { http://dx.doi.org/10.1177/0149206311415280 }\end{array}$ \\
\hline Judg & $\begin{array}{l}\text { Estimated True Score } \\
\text { Correlation }\end{array}$ & $\begin{array}{l}\text { Judge, T.A., Piccolo, R.F. and Ilies, R. (2004) The Forgotten Ones? The Validity of } \\
\text { Consideration and Initiating Structure in Leadership Research. Journal of Applied } \\
\text { Psychology, 89, 36-51. }\end{array}$ \\
\hline Judg2 & $\begin{array}{l}\text { Estimated True Score } \\
\text { Correlation } \\
\text { Sample Size Weighted Mean }\end{array}$ & $\begin{array}{l}\text { Judge, T.A. and Piccolo, R.F. (2004) Transformational and Transactional Leadership: A } \\
\text { Meta-Analytic Test of Their Relative Validity. Journal of Applied Psychology, 89, 755-768 }\end{array}$ \\
\hline Mesm & $\begin{array}{l}\text { Observed Correlation } \\
\text { Corrected for Unreliability in } \\
\text { Both Measures }\end{array}$ & $\begin{array}{l}\text { Mesmer-Magnus, J., Glew, D.J. and Viswesvaran, C. (2012) A Meta-Analysis of Positive } \\
\text { Humor in the Workplace. Journal of Managerial Psychology, 27, 155-190. }\end{array}$ \\
\hline Nahr & $\begin{array}{l}\text { Correlations Corrected for } \\
\text { Sampling Error and for } \\
\text { Measurement Unreliability }\end{array}$ & $\begin{array}{l}\text { Nahrgang, J.D., Morgeson, F.P. and Hofmann, D.A. (2011) Safety at Work: A } \\
\text { Meta-Analytic Investigation of the Link Between Job Demands, Job Resources, Burnout, } \\
\text { Engagement, and Safety Outcomes. Journal of Applied Psychology, 96, 71-94. } \\
\text { http://dx.doi.org/10.1037/a0021484 }\end{array}$ \\
\hline Ng1 & $\begin{array}{l}\text { Sample Size Weighted } \\
\text { Corrected Correlation }\end{array}$ & $\begin{array}{l}\text { Ng, T.W.H. and Feldman, D.C. (2014) Ethical Leadership: Meta-Analytic Evidence of } \\
\text { Criterion-Related and Incremental Validity. Journal of Applied Psychology. }\end{array}$ \\
\hline Oh & $\begin{array}{l}\text { Estimated Mean } \\
\text { True-Score } \\
\text { Correlation }\end{array}$ & $\begin{array}{l}\text { Oh, I.-S., Guay, R. P., Kim, K., Harold, C. M., Lee, J.-H., Heo, C.-G. and Shin, K.-H. (2014) } \\
\text { Fit Happens Globally: A Meta-Analytic Comparison of the Relationships of Person- } \\
\text { Environment Fit Dimensions with Work Attitudes and Performance Across East Asia, } \\
\text { Europe, and North America. Personnel Psychology, 67, 99-152. }\end{array}$ \\
\hline Park1 & $\begin{array}{l}\text { Weighted Mean } \\
\text { Correlations } \\
\text { Corrected for } \\
\text { Unreliability }\end{array}$ & $\begin{array}{l}\text { Parker, C.P., Baltes, B.B., Young, S.A., Huff, J.W., Altmann, R.A., Lacost, H.A. and } \\
\text { Roberts, J.E. (2003) Relationships between Psychological Climate Perceptions and Work } \\
\text { Outcomes: A Meta-Analytic Review. Journal of Organizational Behavior, 24, 389-416. } \\
\text { http://dx.doi.org/10.1002/job.198 }\end{array}$ \\
\hline Pods2 & $\begin{array}{l}\text { N-Weighted Mean } \\
\text { Population Correlation }\end{array}$ & $\begin{array}{l}\text { Podsakoff, P.M., Bommer, W.H., Podsakoff, N.P. and MacKenzie, S.B. (2006) Relationships } \\
\text { between Leader Reward and Punishment Behavior and Subordinate Attitudes, Perceptions, } \\
\text { and Behaviors: A Meta-Analytic Review of Existing and New } \\
\text { Research. Organizational Behavior and Human Decision Processes, 99, 113-142. }\end{array}$ \\
\hline Rock & $\begin{array}{l}\text { Estimated True Score } \\
\text { Correlation Corrected for } \\
\text { Measurement Error }\end{array}$ & $\begin{array}{l}\text { Rockstuhl, T., Dulebohn, J.H., Ang, S. and Shore, L.M. (2012) Leader-Member } \\
\text { Exchange (LMX) and Culture: A Meta-Analysis of Correlates of LMX across } 23 \text { Countries. } \\
\text { Journal Of Applied Psychology, 97, 1097-1130. http://dx.doi.org/10.1037/a0029978 }\end{array}$ \\
\hline Sabe & Pooled Effect Sizes & $\begin{array}{l}\text { Saber, D.A. (2014) Frontline Registered Nurse Job Satisfaction and Predictors over Three } \\
\text { Decades: A Meta-Analysis from } 1980 \text { to 2009. Nursing Outlook, 62, } 6 .\end{array}$ \\
\hline Schy & $\begin{array}{l}\text { Correlation Corrected for } \\
\text { Unreliability Where This } \\
\text { Information was Available in } \\
\text { the Primary Studies }\end{array}$ & $\begin{array}{l}\text { Schyns, B. and Schilling, J. (2013) How Bad Are the Effects of Bad Leaders? A } \\
\text { Meta-Analysis of Destructive Leadership and Its Outcomes. The Leadership Quarterly, 24, } \\
\text { 138-158. http://dx.doi.org/10.1016/j.leaqua.2012.09.001 }\end{array}$ \\
\hline
\end{tabular}

